\title{
Pacific Crossings: Oceania and the Circulation of Literature in the 19th Century
}

Jock Macleod and David Ellison

Griffith University

Australia

It is easy to forget the sheer size of the Pacific Ocean and the multiple independent and post-colonial states bordering it and strewn across its vastness. Indeed, as Matt Matsuda reminds us, 'the Pacific as a named, comprehensive entity is historically European', and it more accurately should be conceived as 'a crowded world of transits, intersections, and transformed cultures' (Matsuda 3). Patterns of language as well as cultural behaviours, material objects and religious practices show that these transits, intersections and transformations have been going on for several millennia. They provide evidence of engagements - and thus cross-cultural relations - well before the era of print, the era most directly associated with 'literature' as we generally conceive it. The 'Asian' Pacific, as it is often called, still shows the evidence of Chinese merchants and warships, Japanese pirates, Vietnamese settlers and Islamic diffusion.

Such engagements overlap, or perhaps more accurately underlie, the kinds of engagements generated by the European Imperial powers and the literature that came with them: first the Portuguese and Dutch from the west and the Spanish from the east in the 16th and 17th centuries, then later the French and the British in the 18th and 19th centuries. Even former Pacific Rim colonies such as the USA and Australia got in on the act in the later 19th and early 20th centuries.

In the 19th century, this crowded world looked very different according to the time and place under scrutiny. Even by the late 19th century, when most of the larger archipelagos of the central and eastern Pacific were 'dominated by trading companies, businessmen, and recognized consuls', making it possible 'for European visitors to move and settle relatively freely' (Lamb et al. 273), Samoa-the focus of Mandy Treagus's piece in this cluster of articles-has little in common with New Zealand at the same time (Kirby Hallum), which is no longer the New Zealand of the 1840s (Lydia Wevers). At any given time, local variations might extend from 'contact' and initial trading, through early settlement and missionary work, to a more 'Westernised' or other established Imperial culture. The western Pacific in the late 19th century, including the Solomons and Papua New Guinea, for instance, was still much closer to early contact with Europeans than were the central and eastern Pacific. 
In regard to the circulation of literature, these local variations were further overlaid by differences both between the publishing and distribution cultures of the European Imperial metropoles and, more critically, within what Robert Darnton has called the 'communications circuit' of any given Imperial literary culture:

[The communications circuit] runs from the author to the publisher (if the bookseller does not assume that role), the printer, the shipper, the bookseller, and the reader. The reader completes the circuit because he influences the author both before and after the act of composition. Authors are readers themselves. By reading and associating with other readers and writers, they form notions of genre and style and a general sense of the literary enterprise, which affects their texts. (Darnton 111)

The variables inherent in such communications circuits can cause the circulation of literature to play out in very different ways. The flow of books from the centres to the peripheries, for example, changed significantly throughout the course of the 19th century as publication methods changed, printing became cheaper and the production of paper more efficient. In the first half of the century in the Anglophone world, the price of books meant that the capacity to build significant personal libraries in the Australian and New Zealand colonies was limited largely to professionals and wealthy graziers. However, as Marc Askew has argued, 'the speed with which colonial white Australians established familiar cultural institutions and imported books and reading materials highlights the close connection between the provincial and metropolitan cultures' (Askew in Macleod and Buckridge, eds, 132). Mechanics' institutes, for example, provided access to books for skilled artisans and lower middle-class readers from as early as 1827 in Australia. By mid-century those readers were turning more and more to fiction (though other forms of 'leisure' reading were also popular), whose supply was met from the 1860s through the establishment of free libraries.

The colonial Anglophone market increased markedly in volume in the last quarter of the 19th century (Askew notes that Australia, for example, increased from $30 \%$ to $40 \%$ of the British book export trade during these years), an increase generated by a number of factors. These included greater educational opportunities through the establishment of schools throughout the colonies (Havelock Ellis was just one of many young English men and women who travelled to Australia to teach in 'the bush' from the 1870), but also improved and faster shipping, along with better and safer transport within the colonies themselves.

Moreover, literature from the metropolis was avidly consumed and discussed in colonial literary circles and societies. In Brisbane in the 1880s and 1890s, for example, well over a dozen such societies flourished in what was still a relatively small city (fewer than 50,000 , even if we combine Brisbane with South Brisbane, at that time a separate city). The Brisbane Literary Circle, the Johnsonian Club, the Brisbane Burns Club, the Shakespeare Reading Society, the Girls' Reading Circle, the Valley Religious and Debating Society, and the Brisbane Freethought Association provide the flavour of what was on offer. As Leanne Day has demonstrated, these societies functioned in quite distinct ways: the Brisbane Literary 
Circle (comprising mainly women), for example, 'believed in literature as a means of achieving the Arnoldian ideal of personal perfection, which could be realised especially through studying the classics', whereas members of the Johnsonian Club (many of whom were journalists, newspaper editors and political figures) 'used their interest in literature ... to progress their own social, cultural and professional interests'; the Burns Club (and the Queensland Scottish Association) celebrated Scottish literature and links to the 'homeland', as one would expect, but it also used literature 'as a practical means of cultural inclusion and outreach to people of all nationalities in the local community' (Day 19-20) So, too, the kind of literature varied, though a common theme across all groups was the function of literature as a broadly civilising influence and a consequent denigration of fiction (with the exception of Maria Edgeworth, Walter Scott, Dickens and a few others).

The arguments promoting 'good' reading in developing civility were, of course, those used in the industrial metropolitan cultures, where the rapidly expanding working and lower-middle classes were the subject of numerous efforts at cultivation. William Booth's famous phrase 'In Darkest England and the Way Out' tends to focus our attention on the African brand of Imperialism as 'the civilising mission', but the fragility of civility was particularly acute in the Pacific, due in large part to the extremity of its distance from the Imperial homelands. Jonathan Lamb, Vanessa Smith and Nicholas Thomas make the point tellingly in the introduction to their collection of historical writings from the Pacific:

Many of the texts we present evince the extent to which civility was in no sense a secure term, nor one that could simply be bolstered through juxtaposition with savagery. Scurvy (the predominant maritime disease in voyages over the Pacific) was well-known to cause acute psychological as well as physiological symptoms, summed up by one expert as "scorbutic nostalgia," a state of enlarged sensibility that inclined the victims to form exquisite ideas of island paradises, and to behave with peculiar abandon when a beach appeared. A range of accounts, from early mutiny histories to the stories of Louis Becke, draw on developing discourses of degeneration to portray white males brutalized by long sea journeys and the circumstances of the beach, whose alienation from "civilized" values finds expression in their defection from the mini-civil society of the ship and incorporation into the indigenous realm. These forms of mutation and hybridity did not simply represent the points between poles that were themselves well-defined, since the failure of civility on the beach tended to prejudice the attributes and operations of European culture in an unconstrained way. (Lamb et al. xviii)

The 'failure of civility on the beach' is the context for Mandy Treagus's article in this cluster, but it is also key to Lydia Wevers' discussion of the Wellington Pickwick Club. Just like the ambitions of the Brisbane Literary Circle 50 years later, 'the self-improving and literary ambitions of the Club', Wevers argues, 
reflect the ways in which colonists thought of themselves, all over the world, as loyal and devoted members of the parent culture who happened to be at the end of a longer journey than their fellow Britons.

However, whereas the liminality of the beach was a thing of the past in 1890s Brisbane, in Wellington in 1840 it was in the forefront of the new colonists' experience. The Pickwick Club, as Wevers notes, 'announced its existence ... less than four months since the New Zealand Company settlers first piled the beach at Petone with their sea-battered belongings'.

This act, in any context, would be extraordinary. In Wevers' words, its extraordinary nature appears even more bizarre:

The settlers had been less than six months on a foreign shore, been flooded out and had to move to the other side of a deep and stormy harbour, and one of their first acts of social organisation was to materialize a fictional club in a novel by a 28 -yearold man whose career thus far consisted of four books.

Asking 'why Pickwick?', she makes a strong case based not just on the enormous popularity of the works of 'Boz' in the late 1830s, but drawing more particularly on what an early report had to say about the Club's first meeting: in 'this land of savages', the Club manifests the importance of 'rules and regulations'. Regulations, so central to the opening chapter of the novel, represent for Wevers, 'a deeply reassuring depiction of social order, despite, or perhaps because of, Dickens's lampoon of the Royal Society'. This of course is not just civility but civility formalised.

Wevers is right to argue that the Pickwick Club 'carried the hope, and you might say expectation, that the Dickensian world would transfer with them [its members]'. But the traffic was not all one way, and it certainly was neither simple nor direct. Take. For instance, the case of Henry Prinsep (1844-1925), who became the first Chief Protector of Aborigines in Western Australia in 1898. Prinsep's father and grandfather had both served with the East India Company, and he himself was born in what was then called Calcutta, though raised in England. In a fine study of Prinsep and his family, based on meticulous archival research, Malcolm Allbrook follows what he calls

a fruitful line of inquiry about a relatively ignored aspect of empire, one in which family and social networks functioned to buttress its formal institutions and often transcended national and colonial boundaries. (16)

This was a family with a global reach, not only in relation to formal politics, but to the arts in general-many of its members had been artists and watercolourists, and Henry Prinsep himself became something of a celebrated photographer. And it is not an isolated case. As Allbrook remarks, 
Prinsep was but one of many Western Australians who lived transnational identities, whose imperial gaze extended far beyond a colony-metropole nexus to incorporate an infinitely more complex world of constantly shifting relationships and exchanges.

Much more research needs to be done in this field, but the careers of colonial administrators, graziers, business leaders, political figures, and newspaper proprietors and editors typically reveal the sorts of complex global relationships Allbrook teases out in the case of Prinsep and his family.

Moreover, the publishing industry itself responded in numerous ways to the broad de-centering of Imperial literary culture, especially in the more populous colonies. The plethora of publishers' series called 'Colonial Library' (or some variant of this) was the most overt of these responses. But there were more subtle forces at work too, akin to Darnton's point about authors being readers themselves and forming 'notions of genre and style and a general sense of the literary enterprise, which affects their texts'. Both Mandy Treagus's and Kirby Hallum's articles address aspects of this process of accommodation.

Since the 17th century, Pacific journeys and encounters had been constructed in ways that made sense to European metropolitan cultures. This was especially the case in relation to the representation of Indigenous women, though as Patty O'Brien has observed in a study of Pacific female exoticism, 'by the middle of the nineteenth century, the differentiations between ethnically different Pacific women were clearly enunciated' (O'Brien 13). How these differences were enunciated in narratives that also fitted with the demands of metropolitan genres is a story of change and negotiation itself. Certainly by the late 19th century, the sense of dislocation and disorientation that had characterised the experiences of earlier explorers and traders was beginning to be manifested in narrative genres themselves.

Robert Louis Stevenson's "The Beach at Falesá" (1892) is such a narrative. As Treagus argues, 'though not as apparently simplistic as most imperial romances, such as those of Haggard, the story reiterates whiteness just as thoroughly as less-nuanced adventure stories'. However, this is not an adventure story written 'from the centre', as it were. Here, the protagonist-narrator Wiltshire, who is married to Uma, an island woman, recalls his time 20 years earlier in the Samoa of the 1870s ('when cultures on beaches were beginning to change and solidify' after earlier contact), his narrative ending 'with Wiltshire wealthy and firmly grounded in the Pacific, his main dilemma the fate of his mixed-race children'.

In her analysis, Treagus shows how in this story, 'racist taxonomies are forced to become flexible, and thereby begin to come undone, especially for the imperial reader'. She contextualises this in relation to the Stevensons' own concerns with 'afakasi (mixed-race children): in 1892 they started the Vine-ula Club for Samoans and 'afakasi whose purpose 
was to help them learn how to function socially in western ways. The aim of meeting weekly 'for amusement and improvement' is redolent of Wellington's Pickwick Club, the Brisbane Literary Circle and numerous other such clubs and circles throughout the colonial world. But here, even if the civilising principle were the same, the focus was dance rather than Dickens or Arnold. As Treagus notes, many of the Stevensons' friends were families consisting of British or American men married to Samoan women, who had mixed-race children. These children, 'grew up in the world of the beach; they did not live traditional Samoan lives, but rather were enculturated in the new hybrid world'. As a writer, Stevenson is writing from the Pacific as much as writing about the Pacific, and it is his increasing grounding in this location that enables him to move beyond the earlier adventure romance of Treasure Island (1883) to the 'hybrid realism' of "The Beach at Falesá". Treagus completes her analysis by suggesting that in 'The Ebb-Tide' (1894), Stevenson 'goes further than this, seemingly abandoning the genre altogether', and in the process empties the colonial enterprise 'of all possible meaning'. In short, because the genre circulated with the transits of imperialism, once the imperial project started to be undermined from its peripheries, so too the genre started to be undermined.

For Hallum, too, a 'European' genre (New Woman fiction) is re-constituted from a periphery, though here the perspective-New Zealand-might more accurately be described as postcolonial. In her article, she makes a case for 'the specific social experience of New Zealand producing a distinct version of the New Woman' in Julius Vogel's Anno Domini 200; or, Woman's Destiny (1889), Louisa Alice Baker's A Daughter of the King (1894), and Edith Searle Grossmann's The Heart of the Bush (1910). Vogel, who went on to become Prime Minister, was a champion of women's rights, and introduced the first Women's Suffrage Bill to the New Zealand Parliament in 1887 (unsuccessfully, though suffrage was granted in 1893, long before becoming law in the English metropole). Hallam's analysis of Vogel's novel concludes by drawing our attention to the way it

mobilises the New Zealand New Woman figure in his literary vision of imperial egalitarianism ... [and] suggests in his [Vogel's] alternative future the New Woman is no longer betwixt and between, but at home in her own country and the rest of the federated Empire.

The reference to being 'at home' triggers Hallum's analysis of the other two novels under discussion, and it also resonates with the broader emphasis on the Pacific in this cluster of articles. Baker, for instance, demonstrates in her fiction 'the unsettledness of woman's position in the colony' and her use of the pseudonym 'Alien' when she relocated to England to pursue a literary career 'reflects her sense of displacement from both the English homeland and her New Zealand home'. A Daughter of the King plays out the journey of female self-discovery, as the heroine, Florence, leaves a loveless marriage and home to search for success as a musician in Melbourne, whose metropolitan status, Hallum reminds us, 'is the closest realisation to London in terms of culture'. Here the journey is 
away from the Pacific ('home') towards the metropolis, whose own space and capacity to isolate and disorient are precisely the characteristics of the Pacific experienced by male explorers and travellers who had journeyed from their metropolitan home. Indeed, Florence's desire to be released from her husband, her desire to 'let go', is fulfilled by just the sensuality attributed to exotic Pacific primitivism, except here it is the world of art: playing her violin to a capacity Melbourne audience, she triumphs 'over her old agonies; vibrating to every touch, her genius awoke'.

This journey of female artistic discovery from island to metropolis appears to be the mirror image of the geographical journey of discovery characteristic of narratives of the Pacific. But it is not an exact mirror image. Florence in a sense crosses the beach, because, although she moves back to New Zealand (for the sake of her children), she then returns again to Melbourne after settling affairs with her husband. However this beach needs to be seen from the perspective of the island, not the ship, and the movement from a state of (unacceptable) servitude to one of liberating civilisation and culture. Here the binaries cross over, but the civilisation (ship)/nature (island) binary of the earlier explorer and adventure narratives is not strictly reversed but distorted by the Western feminist narrative of female liberation and a Pacific location that had long passed its 'contact zone' origins.

Grossmann's The Heart of the Bush, by contrast, 'embraces the colonial homeland, especially the isolation and wildness of the Canterbury location in which it is set'. Here, Hallum argues, the New Woman heroine eventually rejects 'England and all it stands for in favour of settling for a New Zealand home'. In particular, Hallum draws attention to passages describing the landscape where 'phallic symbolism, codified female genitalia, and images of lush nature' enable Grossman to operate within the framework of New Woman fiction's endorsement of female sexuality, but to position that framework within the specifically colonial (Pacific) context. Like Stevenson's very different story, this is a text written from a periphery that encapsulates but seriously complicates the metropolitan genre. Here the sexually potent 'natural' woman is not an ahistorical object of male desire (the metropolitan text), but a progenitor of her own history; nature and history merge, the 'beach' no longer a liminal space of disorientation and conflict, but the space where conflict is resolved.

If there has been a common theme to this cluster of articles about literature in and from the Pacific, it is that the multiple histories and locations covered by the concept of 'the Pacific' deeply complicate any assumptions we might have about the ways in which Empire and colonialism might have contributed to the circulation of that literature. From the Wellington Pickwick Club's recourse to what was already being regarded as a quintessential 'English' writer as a means of buttressing their own civility in the immediate aftermath of landing on the beach, to Robert Louis Stevenson's experience and depiction of hybridity on the beach (already incipient in his Scottish discomfort with English culture), through to Louisa Alice Baker's and Edith Searle Grossmann's portrayals of crossing the beach from the 
perspective of the New Woman, Lydia Wevers, Mandy Treagus and Kirby Hallum offer us new insights into the global circulation of literature in the Pacific in the 19th century.

\section{Works Cited}

Allbrook, Malcolm. "Imperial Family": The Prinseps, Empire and Colonial Government in India and Australia. PhD, Griffith University, 2008.

Askew, Marc. 'Reading and the Australian Reading Public: Some Historical Considerations'. Books and Reading in Australian Society. Eds. Jock Macleod and Patrick Buckridge. Brisbane: ICPS, 1992. 129-46.

Darnton, Robert. The Kiss of Lamourette. London: Faber \& Faber, 1990.

Day, Leanne. Civilising the City: Literary Societies and Clubs in Brisbane During the 1880s and 1890s. PhD, Griffith University, 2005.

Lamb, Jonathan, et al., eds. Exploration and Exchange: A South Seas Anthology 1680-1900. Chicago: University of Chicago Press, 2000.

Matsuda, Matt K. Pacific Worlds: A History of Seas, Peoples, and Cultures. Cambridge: Cambridge University Press, 2012.

O'Brien, Patty. The Pacific Muse: Exotic Femininity and the Colonial Pacific. Seattle: University of Washington Press, 2006. 